\title{
THE QUESTION OF ENERGY AND CONSIDERATION OF ITS PLACE AND IMPORTANCE IN CLASSICAL AND NEOCLASSICAL THEORY OF GROWTH AND DEVELOPMENT
}

\author{
Vladimir Kostic ${ }^{*}$ \\ Faculty of Economics, University of Priština, Republic of Serbia \\ Ivana Vučić \\ Public enterprise Transnafta, Pančevo, Republic of Serbia \\ Jovana Majstorović \\ Serbian Association of Managers, Belgrade, Republic of Serbia
}

\begin{abstract}
Energy is crucial in all processes, including the process of economic growth. The process of economic growth involves the transformation of raw materials into the final product, which means the use of energy. The paper examines the importance of energy for contemporary economic development and points to the necessity to move from the use of non-renewable to the use of renewable energy resources. The undoubted connection between economic growth and energy consumption, as well as the divergent views of economic researchers regarding the causality of economic growth and energy consumption, was established, which is of crucial importance in the creation of energy policies of individual countries. The dominant position in economic science is confirmed by which the energy in classical theory is implicitly included in economic activity across the country as a key factor of production. On the contrary, in neoclassical economic theory energy was not recognized as an important productive factor, which at the same time represents one of its most pronounced weaknesses.
\end{abstract}

Key words: energy, economic growth, economic development, energy resources, classical growth theory, neoclassical growth theory

JEL Classification: $013,044, P 48, Q 43$

*vladimir.kostic@pr.ac.rs 
118 | THE QUESTION OF ENERGY AND CONSIDERATION OF ITS PLACE AND IMPORTANCE IN CLASSICAL AND NEOCLASSICAL THEORY OF GROWTH AND DEVELOPMENT

\section{PITANJE ENERGIJE I SAGLEDAVANJE NJENOG MESTA I ZNAČAJA U KLASIČNOJ I NEOKLASIČNOJ TEORIJI RASTA I RAZVOJA}

Sažetak: Energija je od ključne važnosti u svim procesima, uključujući $i$ proces ekonomskog rasta. Proces ekonomskog rasta podrazumeva transformaciju sirovina $u$ finalni proizvod, što per se znači upotrebu energije. U radu je učinjen osvrt na sagledavanje značaja energije za savremeni ekonomski razvoj i ukazano je na nužnost prelaska sa upotrebe neobnovljivih na korišćenje obnovljivih energetskih resursa. Konstatovana je nesporna povezanost ekonomskog rasta $i$ potrošnje energije, ali $i$ divergentni stavovi ekonomskih istraživača po pitanju kauzalnosti ekonomskog rasta $i$ potrošnje energije, što je, pak, od krucijalnog značaja kod kreiranja energetskih politika pojedinih zemalja. Potvrđen je dominantan stav u ekonomskoj nauci po kome je energija u klasičnoj teoriji implicitno uključena u ekonomsku aktivnost preko zemlje kao ključnog faktora proizvodnje. Suprotno ovome, neoklasična ekonomska misao nije prepoznala energiju kao važan proizvodni činilac, što ujedno predstavlja jednu od njenih najizraženijih slabosti.

Ključne reči: energija, ekonomski rast, ekonomski razvoj, energetski resursi, klasična teorija rasta, neoklasična teorija rasta

\section{INTRODUCTION}

Energy presents an important source of economic growth and the inevitable driving force of all economic activities. Therefore, the economy should be viewed as an energy system consisting of energy flows and conversions that culminate precisely in the production of goods and services (Imran and Siddiqui, 2010, p. 206).

Energy is a relatively new factor when it comes to its inclusion among the main drivers of economic growth. The inclusion of energy in models of economic growth during the eighties of the previous century is a consequence of a number of factors. First, the basic laws of thermodynamics suggest that energy is crucial in all processes, and thus it is also included in the process of economic growth. Then, economists, dealing with environmental issues, give priority to energy over all other growth factors. Thirdly, the volatility of energy prices creates more or less difficulty for countries that import energy products (especially oil) in their balance of payments, which inevitably leads to a slowdown in economic growth. Fourth, two important principles have been noted: although wealth with natural resources and energy sources can undoubtedly be useful, it is not only crucial for economic growth and development but also - if not exploited in the right way - it can pose a serious impediment to overall economic development 
Vladimir Kostić, Ivana Vučić, Jovana Majstorović | 119

and completely change the structure of the economy and disable its evolution. Thus, the concept of a "curse of resources" has become a generally accepted legality in economic literature. Parallel, a phenomenon called the "Dutch disease" exposes to risk the productive sector of the country that exports natural resources, including oil, through continuous pressure on the appreciation of the local currency (Apergis, El-Montasser, Sekyere, Ajmi and Gupta, 2014).

Starting from the previously stated conclusions, the subject of the work relates to the categories of energy and energy resources, as well as their place and role in classical and neoclassical growth theory. The goal of the work is to indicate the imperative of switching from the use of non-renewable sources to the use of renewable energy resources in global relations, pointing to the relationship between energy consumption and economic labor, as well as the understanding of the place and role of energy in the classical and neoclassical theory of economic growth. A special accent was put on the critique of neoclassical theory because of minimizing the viewing of energy as a factor of economic growth.

The general scientific methods and elements of logical approach were applied in the research: inductive and deductive conclusion, analysis and synthesis, as well as the historical method and qualitative analysis.

The structure of work is adapted to the object and purpose of the research. After the introduction, the first section of the paper describes the shift of research focus in macroeconomic theory from economic growth to development that occurred in the years of the seventh decade of the previous century. In the third section, a review of the imperative of using energy from renewable sources is made. The fourth part explains the dependence between energy consumption and economic growth. Then, in the fifth section, the vision of energy and energy resources as a growth factor in the classical economic theory is presented. In the sixth section, a critique of the neglect of the importance of energy as a driver of growth by neoclassical theoreticians is stated. In the seventh section of the paper final conclusions are presented.

\section{SHIFTING FOCUS OF THE RESEARCH FROM ECONOMIC GROWTH TO ECONOMIC DEVELOPMENT}

Economic growth relates to $t$ increasing the value of a country's production over time. Stable production growth is an important prerequisite for solving the central economic task in each community, defined as an attempt to satisfy the growing needs of people as much as possible by using always limited resources (Sredojević, Cvetanović and Bošković, 2016). 
120 | THE QUESTION OF ENERGY AND CONSIDERATION OF ITS PLACE AND IMPORTANCE IN CLASSICAL AND NEOCLASSICAL THEORY OF GROWTH AND DEVELOPMENT

Economic growth can be achieved in two basic ways, by increased use of factors and by the same amount of factors of increasing efficiency of use. Economic growth is a long-term and slow process. At first glance, slight changes in the average rate of economic growth over a longer time interval can lead to a very different level of gross domestic product per capita.

Economic growth is a precondition for increasing the living standard of people, i.e. the assumption of economic welfare growth. It relativizes the contradiction between unlimited needs, on one hand, and always limited production resources, on the other. More specifically, in the conditions of dynamic economic growth, the choice of social goals is far simpler and incomparably less contradictory than in the case when the national economy does not have an increased production of goods per capita. However, the dynamic economic growth of many countries after the Second World War did not result in poverty reduction in them. "Despite the impressive results achieved in increasing production, the living level of the mass population in those countries remained largely unchanged, or even worsened" (Jovanović Gavrilović, 2013, p. 5). This fact worked towards the creation of a new perspective on economic development, a view that unites the expansion of total production and an increase in equity in the distribution of the newly created value.

Economic development is often narrowly defined as "constant economic growth" (Todaro and Smith, 2015). The further step presents the development of economic growth and complex changes in the structure of the economy, as well as the changes in the distribution of income (Nafziger, 2012).

Shifting the focus of research from economic growth to development posed issues such as poverty, unemployment and income inequality, but it did not brought about major changes in the structure of the world economy. Access to economic development is fundamentally different, but economy has not changed much over the past decades.

The general characteristic of the many approaches to the study of economic development is the evident partiality in perceiving the key causes of the poverty of individual nations. The lack of a synthetic view of the problems concerning underdevelopment is a characteristic feature of most developmental theories. On the whole, there are few papers that competently explore the method of accepting the incorporation of certain developmental problems into a compact entity. 


\section{IMPERATIVE TRANSMISSION FROM THE USE OF INNOVATIVE TO THE USE OF RENEWABLE ENERGY RESOURCES}

The world today is burdened with a constantly growing concern for the provision of sufficient quantity and adequate energy. Through the use of various sources of energy, humankind managed to increase production continuously over the last two hundred years or more, and improve the living standard (Mandal, Mihajlović, Milanović and Nikolić 2010, p. 6). However, energy sources that have been more than two centuries of crucial importance for global development, today, due to the release of carbon dioxide, they are increasingly endangering the environment. On the other hand, all projections of energy consumption show its increase in energy demand in the coming years. Therefore, it seems that "of all the problems associated with the harmonization of growth with planetary boundaries, in their own way, none is more urgent, and at the same time more complex than the challenges facing the world energy system" (Saks, 2014, p. 186).

The history concerning energy is marked by a series of revolutions associated with new energy products (coal, oil, electricity) and new technologies that use them (steam engine, motor vehicles, information and communication technologies (Kander and Stern, 2014).

The most used energy resources in the modern world, which in the past two centuries have affected the dynamic technological and economic development, oil and nuclear energy, have shown in the last decades of the twentieth century irreparable harm. The organization of economic life today predominantly relies on the use of fossil fuels, which leads to an unstoppable increase in their consumption, while simultaneously degrading the environment and intensifying the dependence and poverty of those who do not have this type of energy resources in their possession (Cvetanović and Despotović, 2014, p. 43).

In the second half of the twentieth century, it was understood that the use of non-renewable energy resources brought two unsolvable problems to mankind. One is that each new generation will face the scarcity of these resources, and the other is that their overuse will disturb the environment. This has brought to question the cost-effectiveness of the use of non-renewable energy resources, as the fact that in their cost must inevitably be calculated costs of elimination of the harmful consequences of their use became more evident (Despotović, 2011).

All major recessions are accompanied by energy shocks, and energy price increases fuel inflation expectations. The global energy crisis of the 1970s 
122 | THE QUESTION OF ENERGY AND CONSIDERATION OF ITS PLACE AND IMPORTANCE IN CLASSICAL AND NEOCLASSICAL THEORY OF GROWTH AND DEVELOPMENT

caused by the escalation of crude oil prices is one of the warning signs that uncontrolled and irrational use of energy inevitably leads to the emergence of global economic disorders. The energy crises of the 1970s clearly underscored the vulnerability of the world energy system, predominantly based on the consumption of non-renewable energy sources, the inflexibility of consumption and the need to replace them with renewable energy sources. It is therefore not surprising that "energy has become one of the priority topics of the European Union. Although this is still a topic and the competence of Member States and their national policies, the European Union is working on the formation of a common energy policy. Energy and the fight against climate change are two sides of the same coin" (Cvetanović, Kostić and Milačić, 2016, p. 261).

Limited reserves of non-renewable resources make urgent increased use of renewable energy resources. Many data indicate that the world is dangerously approaching the limit of depletion of conventional energy resources and facing ever more serious energy problems.

Energy resources: solar energy, biomass, wind, hydropower represent various combinations of solar energy and the presence of water in the atmosphere. This combination represents the essence of the climate, and these resources are considered as climate resources. Life on planet Earth was created and it has survived for millions of years thanks to precisely those resources, or in other words, favourable climate.

High concentration of energy in fossil fuels (coal, oil, natural gas) and radioactive uranium has greatly accelerated production over the past two centuries. Already in the second half of the twentieth century, it was understood that the use of fossil fuels and nuclear energy brought two unsolvable problems to mankind. One is that the already modern generation will face the scarcity of these energy sources, and the other is that these energy sources pollute the environment. This has also raised the question of their cost-effectiveness, because their cost often does not include the recovery of harmful consequences. Clearly, non-renewable resources do not have a long-term perspective, but it is difficult to make a rapid shift in the current way of life, which requires large investments, as well as major changes in people's habits.

Ignoring the damaging impact of the use of non-renewable energy sources on the environment and climate, the most important weakness, from the point of view of further development, concerns the fact that reserves are limited. The basic solution is to make a reorientation to non-constrained sources, which means, to energy that is constantly renewed. The renewable energy is solar energy and forms of energy that represent its various variants. This is the energy of water, wind and biomass. 
Vladimir Kostić, Ivana Vučić, Jovana Majstorović | 123

The use of wind and solar energy has experienced great expansion today in the world. In addition to ecologically clean energy, an important factor for significant expansion is the fact that the exploitation of renewable energy sources has become economically competitive. Forecasts for half of this century indicate that more than half of the total energy consumption will be solar energy and energy derived from biomass (Despotović, 2011).

\section{ENERGY CONSUMPTION AND ECONOMIC GROWTH}

The relationship between energy consumption and economic growth, measured by the size of gross domestic product, has started to be intensively explored in economy since the beginning of 1970s (Caraiani, Lungu and Dascălu, 2015). The reasons that have affected the growing interest of economic analysts in energy consumption issues are numerous. First of all, it is important to understand this relationship because of the importance of energy for economic growth (Stern, 2011). Also, it becomes increasingly evident that the effect of energy price impacts on the manifestation of various economic imbalances (Hamilton, 2009) is of no less importance than the role of energy in explaining the key causes of climate change (Ang, 2006).

Within the defined object and purpose of the research in this paper, it is of utmost importance to see the existence and especially the nature of the connection between these two categories. It can be said that if the connection between economic growth and energy consumption is a generally accepted fact, the causality of this relationship is not (Stern and Cleveland, 2004).

Empirical results regarding the existence of causality between energy consumption and economic growth are different. For example, Chontanawat et al. (2008) studied the relationship of conditionality between gross domestic product (GDP) and energy on a large sample of member countries of the Organization for Economic Cooperation and Development (OECD) and those that did not belong to the OECD. They concluded that conditionality in the direction of energy to GDP was more pronounced in developed OECD countries than in non-OECD countries, which implies that a policy of reducing energy consumption aimed at reducing emissions, will probably have a greater impact on GDP developed part of the world than developing countries. However, there are studies in which it is concluded that, in less developed countries, oil consumption causes economic growth, while in highly developed European countries, economic growth causes oil consumption (VlahinićDizdarević, 2009).

Conclusions on the causality between energy consumption and economic growth can be summed up over the following four paragraphs:

SCHOOL OF BUSINESS, 2/2018, 117-132 
124 | THE QUESTION OF ENERGY AND CONSIDERATION OF ITS PLACE AND IMPORTANCE IN CLASSICAL AND NEOCLASSICAL THEORY OF GROWTH AND DEVELOPMENT

- there is no causality between energy consumption and economic growth,

- there is a mutual causality between energy consumption and economic growth,

- there is a one-way causality that goes from economic growth to energy consumption, i.e. economic growth affects the increase in energy consumption, but without feedback, and

- there is a one-way causality that goes from energy consumption to economic growth, i.e. energy consumption affects economic growth, but without feedback (Erić, 2016).

Determining the existence of a causal relationship between economic growth and energy consumption relates to the formulation of competent energy policies, which become an increasingly important part of the economic policies of most modern economies. In cases where a one-way causality from energy consumption to economic growth has been proven, an energy policy that restricts energy consumption or favors the growth of energy prices will proportionally reduce economic growth. It points to the need for more efficient use of energy on one hand, and the restructuring of the economy towards the development of less energy-intensive production sectors, on the other (Erić, 2016, pp. 36-37).

In the case of proven one-way causality from economic growth to energy consumption, energy policy can limit energy consumption by various measures without the risk of endangering future economic growth. Also, scarcity in energy resources would not cause more serious restrictions on economic growth.

When mutual reciprocity between energy consumption and economic growth is accepted, measures restricting energy consumption will most likely act to slow down the intensity of economic growth.

Finally, when there is no causality between energy consumption and economic growth, energy policies that include energy savings, i.e. the availability of limited energy resources within one country, should not affect economic growth (Erić, 2016).

Different degrees of causality between energy consumption and economic growth are conditioned by a whole range of factors. The most significant are: changes in the structure of the economy, climate change, differences in living standards, changes in the structure of energy depending on the degree of its usefulness, etc. (Mandal, Mihajlović Milanović and Nikolić, 2010, p. 6.) 


\section{ENERGY IN CLASSICAL ECONOMIC THEORY}

Although representatives of classical economic theory emphasized the key role of country in economic growth, they did not directly recognize energy as a factor of production. Namely, classics use terms such as "fertility of nature" (Adam Smith), "productivity and indestructible power of the earth" (David Ricardo), "natural and inseparable power of the earth" (John McCulloch) or when they use the term "miraculous chemical workshop of mixed materials and elements" (Jakovac and Vlahinić Lenz, 2015; Allen, 2009).

Accentuating of the earth as a factor of production was possible at a time when this resource was widely available and when the population simply spread to the increasing parts of the country. Wages were equal to total national income because there was no deduction for rent and interest. In such circumstances, production has continued to grow at the same time as the growth in population, while real wages over time have become constant. However, when free country disappeared, the balanced growth of land, labour and production was no longer possible. New workers have begun to accumulate on arable land. The country as a growth factor becomes scarce and rents occur in order to rationalize the land for different uses. The population continues to grow in the same way as domestic products, but in this case production must grow slower than the population. Regarding the rent, David Ricardo claims that each land would have the same properties, and if the land was unlimited in quantity and uniform in quality, it would not be possible to claim a charge for its exploitation unless it had special advantages concerning its position. The rent is, therefore, paid for land utilization only because the land is not unlimited in quantity or in terms of quality, and because along with the growth of population the land of poorer quality and unfavourable position is cultivated. When due to the advancement of the society, the secondary land begins to be cultivated, an annuity on the first-class land immediately appears, and the amount of that annuity depends on the difference in quality of the land. The amount of land annuity therefore varies according to the intensity of the processing, according to the location of the land in relation to the market and according to the quality of the land. Thus, classical economic theory assumed that the land was available in unchangeable quantities and sometimes of variable quality. In the past, the necessary condition for constant and sustained growth was to gain abundant land yields. Under such conditions almost all raw materials used in the production process were either animal or plant origin of the soil. If they were mineral raw material, then they had to be transformed into a useful form using heat energy. Each increase in agricultural production implied higher yields, but due to the limited use of less quality land it became a necessity" (Wrigley, 2010). The fixed character of the 
126 | THE QUESTION OF ENERGY AND CONSIDERATION OF ITS PLACE AND IMPORTANCE IN CLASSICAL AND NEOCLASSICAL THEORY OF GROWTH AND DEVELOPMENT

country's supply creates a tendency for declining returns of labour and capital which are used in agricultural production. Here, it is discussed about the intensive border (more inputs applied to the same country), or the extensive border (equal inputs applied to different types of land). The growing relationship between labour and the country leads to a decline in the boundary product of labour and a reduction in real wages. In other words, classical economists argue that Malthusian demographic mechanism (and its concern over the existence of scarcity or the rarity of natural resources) in interaction with declining yields in agriculture over time leads the economy towards a steady state characterized by constant levels of capital and population. This leads to the conclusion that natural resources (in this case, the land) represent the limits of unhindered economic growth (Wrigley, 2010).

It turns out that energy in classical economic theory is tacitly included in economic activity (through the country as a key factor of production).

\section{MINOR SIGNIFICANCE OF ENERGY IN NEOCLASICAL THEORY}

Neoclassical economic theory does not even implicitly position energy in its macroeconomic framework. Robert Solow does not include natural capital in the model of economic growth. Neoclassical economy, unlike classical, does not treat the land, i.e., soil as a factor of production. The reason for the omission of the land as a factor of economic growth is found in the treatment of land as a co-ownership of physical capital, which belongs to the so-called "primary" factors of production, unlike fuel, materials and raw materials that belong to intermediate factors of production. The research interests of neoclassical economists are focused on the primary factors of production. Intermediate factors are only an indirect matter.

Robert Solow's model of economic growth includes three factors of production; physical capital, labour and technological changes (Dragutinović, Filipović and Cvetanović, 2016). It does not include energy and energy resources. This implicitly means that the attitude of neo-classicists is that economic growth can be done efficiently regardless to the demand for energy resources. The argument in favour of such an assumption is in the aforementioned technological change, or in their attitude according to which the substitution of production factors is possible. Namely, Robert Solow's growth model assumes that production factors are mutually independent. This means that the change in the quantity of one factor is independent of the change in the amount of other factors by which the productive factors are considered (almost) perfect substitutes. In this case, exploited resources or degraded environmental services can be replaced by equivalent forms of other natural resources or physical capital. Thus, equivalent 
Vladimir Kostić, Ivana Vučić, Jovana Majstorović | 127

substitutes can serve as a way of achieving stable and sustainable economic growth in times of scarcity of energy resources. Energy and energy resources do not constitute an obstacle to economic growth in the opinion of neo-classicists. This is due to the fact that in the neoclassical theory of economic growth, energy efficiency is considered a part of technological progress. Robert Solow's economic growth model was once extended and as such included nonrenewable and renewable energy sources. Because of the a priori assumption that it is technically possible to substitute natural capital for physical, achieving sustainable economic growth in the expanded model is based on the appropriate institutional environment which enables the mentioned substitution. The standard macroeconomic application of the expanded neoclassical model of economic growth was absent, the only contribution of energy was seen through the relative share of energy costs in production, and the expanded growth model was applied only in discussions about the protection and sustainability of the environment (Ockwell, 2008).

Neoclassical economics believes that in countries that have moved from preindustrial into industrial phase there will be no shortage of natural and energy resources for two reasons: 1) the growth in resource prices will affect their more efficient consumption; 2) the growth in resource prices will stimulate innovation that will result in an adequate substitution of natural capital. Basically, that is the wrong interpretation. Namely, the efficient use of energy resources as a result of the development and application of energy-efficient technologies in the final analysis leads to higher consumption of non-renewable and excessive consumption of renewable energy sources. It is a rebound effect, which is also known in the literature as the Jevons Paradox. Substitution, however, requires time, and the elasticity of the substitution between energy, i.e. natural and physical capital is low anyway (Stern, 2011). Since industrial societies depend entirely on the functioning of their own infrastructure, the possible interruption of production as a result of the untimely invention of the appropriate substitute for fossil fuels increases the risk of collapse of the entire system. The vulnerability of neoclassical economic theory stems from the premise that the market will determine the dynamics of the transition from fossil fuels to adequate substitutes through a price mechanism (in the way that energy prices will affect the transition dynamics) and through innovation capacity, as it will appear whenever it is necessary thought that innovation (Cleveland and Constanza, 2008).

Due to the omission of the land from the macroeconomic framework, the neoclassical economy has crossed a link among the economy and natural energy resources and economic growth. In other words, innovations will appear early enough to avoid a long-term stagnation in the operation of the entire SCHOOL OF BUSINESS, 2/2018, 117-132 
128 | THE QUESTION OF ENERGY AND CONSIDERATION OF ITS PLACE AND IMPORTANCE IN CLASSICAL AND NEOCLASSICAL THEORY OF GROWTH AND DEVELOPMENT

infrastructure, and in this way it will exclude energy from the economic system. Furthermore, because of the allocation of the land, there is no need, in contrast to classics, to divide the economy into two sectors. An additional reason why energy is not included in economic activity is to treat energy as a raw material, or more precisely as an intermediate good. Neoclassical economics observes energy and energy resources as analytical equivalents by factors that do not bring any energy into the process of production (such as iron, glass, plastics, timber, etc.). Therefore, in neoclassical growth theory, the importance of energy as a factor of economic growth is minor (Alam, 2008). Neoclassical economists believe that economic growth is the result of an increase in capital equipment and technological advancement. Neoclassical growth theory has envisaged the conclusion according to which the stable supply of energy is a necessary source of economic growth, and capital and labour are simply intermediaries in the exploitation, transformation and direction of energy resources in terms of production and consumption of goods and services. In other words, standard (neoclassical) factors of production and growth are nothing more than energy transformers (Jakovac and Vlahinić Lenz, 2015). Neoclassical economic thought did not recognize energy as a key production resource while Robert Solow's economic growth model defines economy as a closed system in which goods and services are produced by the use of capital and labour. In such a system, economic growth is achieved by larger quantities and / or higher quality inputs, or technological progress, and energy inputs have only an indirect role and are treated as intermediate goods (Vlahinić Dizdarević and Žiković, 2011, p. 6).

In most of the literature devoted to the study of economic growth, it is discussed how more prominent economic growth works on higher energy consumption, and not vice versa. Therefore, economic growth is considered the main factor in demand for energy, while only advanced economies with a high degree of innovation potential can reduce energy consumption without compromising economic growth. The literature of the neoclassical economic paradigm on this issue is somewhat limited. While business and financial analysts pay considerable attention to the impact of oil and other energy prices on economic activity, neoclassical growth theory marginalizes the role of energy and energy resources. However, a sharp rise in oil prices after the first oil crisis in the early 1970s initiated a debate on the causes of productivity slowdown, and initiated deeper reflection on the importance of energy resources for economic growth. Until then, a largely limited neoclassical consideration of the role of energy and energy resources has become a subject of criticism from various economic schools that do not belong to the so-called "mainstream economics" (VlahinićDizdarević and Žiković, 2011, p. 4; Erić, 2016, p.). 


\section{Vladimir Kostić, Ivana Vučić, Jovana Majstorović | 129}

\section{CONCLUSION}

During the history of the development of economic theory, energy and energy resources as factors of economic growth were not given explicit importance. In economic theory and practice, energy is usually treated as an intermediate good. According to neoclassical models, economic growth is dominantly attributed to the category of technological changes, i.e. to knowledge commercialized in innovation.

According to economic theory, the amount of energy that is available to a particular economy was endogenously determined by biophysical and economic boundaries. However, it is quite logical that a certain driving force must enable growth factors such as land, labour, capital, organization, production technology in the process of economic activity to result in the growth of gross domestic product. And this is energy. In other words, energy allows economic activity to take place over time.

Economists did not pay much attention to energy, as one of the key development factors, but after oil shocks, that happened in the 1970s, they started to pay more attention to this factor and to its impact on the entire economy.

Factors that affect economic growth have been the subject of research in various areas of economic science for years. By examining these key factors, researchers simultaneously analyse both growth mechanisms and its variability. Although the classical theories of the Ricardian economy are primarily based on Malthus's growth model, growth models included only two basic factors - work and capital; today in science there is consensus that they have neglected the impact of technological progress, as well as the effects of economies of scale by assuming the fact that benefits decrease because more basic factors are invested in growth.

Neoclassical economic thought did not recognize energy as a key productive resource while Robert Solow's economic growth model defines economy as a closed system in which goods and services are produced by the use of capital and labour. In such a system, economic growth is achieved by larger quantities and / or higher quality inputs or technological advancement. Energy inputs, according to neoclassical economists, have only an indirect role and are treated as intermediate goods. In short, the exclusion of energy from neoclassical models represents their significant disadvantage.

Neoclassical growth theory is predominantly based on the law on decreasing yields. In principle, the question is whether it is possible at all to describe an increase in production if the explanation is based on the growth of the factors SCHOOL OF BUSINESS, 2/2018, 117-132 
130 | THE QUESTION OF ENERGY AND CONSIDERATION OF ITS PLACE AND IMPORTANCE IN CLASSICAL AND NEOCLASSICAL THEORY OF GROWTH AND DEVELOPMENT

which yields are decreasing. This theory failed to take into account the role of institutions and entrepreneurship that promote economic growth. It focuses too much on scenarios and processes in the short term, without providing long-term solutions and using the population as a whole, which increases unsustainable development. The neoclassical model is based on the premise of poor sustainability, that is, on the concept of not using the total amount of capital. Eventually, a neoclassical approach allows natural and energy resources to be fully consumed as long as other forms of capital compensate for this loss.

\section{REFERENCES}

Allen, R. (2009). The British industrial revolution in global perspective. Cambridge: Cambridge University Press.

Ang, B. (2006). Monitoring changes in economy-wide energy efficiency: from energy-GDP ratio to composite efficiency index. Energy Policy, 34(5), 574-582.

Alam, M. (2008). Bringing energy back into the economy, Department of Economics, Northeastern University, Boston, Working Paper.

Apergis, N., El-Montasser, G., Sekyere, E., Ajmi, A. N., \& Gupta, R. (2014). Dutch disease effect of oil rents on agriculture value added in Middle East and North African (MENA) countries. Energy Economics, 45, 485490.

Cleveland, C., \& Constanza, R. (2008). Biophysical economics. In Cleveland, C. (Ed.), Encyclopedia of Earth, Environmental Information Coalition. Washington: National Council for Science and the Environment.

Caraiani, C., Lungu, C., \& Dascălu, C. (2015). Energonsumption and GDP causality: A three-step analysis for emerging European countries. Renewable and Sustainable Energy Reviews, 44, 198-210.

Cvetanović, S., \& Despotović, D. (2014). Kapital, održivi razvoj i ekonomska politika. Niš, Republika Srbija: Filozofski fakultet Univerziteta u Nišu.

Cvetanović, S., Kostić, V., \& Milačić, Lj. (2016). Evropska unija. Priština, Republika Srbija: Ekonomski fakultet.

Despotović, M. (2011). Obnovljivi izvori energije. Kragujevac, Republika Srbija: Fakultet inženjerskih nauka.

Dragutinović, D., Filipović, M., \& Cvetanović, S. (2016). Teorija ekonomskog rasta i razvoja. Beograd: Centar za izdavačku delatnost Ekonomskog fakulteta Univerziteta u Beogradu. 
Vladimir Kostić, Ivana Vučić, Jovana Majstorović | 131

Erić, M. (2016). Ekonomski razvoj i energetska efikanost: modelovanje odnosa $i$ meta-analiza (Doktorska disertacija). Beograd: Univerzitet Singidunum.

Hamilton, J. (2009). Causes and Consequences of the Oil Shock of 2007-08. National Bureau of Economic Research.

Imran, K., \& Siddiqui, M. (2010). Energy Consumption and Economic Growth: A Case Study of Three SAARC Countries. European Journal of Social Sciences, 16(2), 206-213.

Jakovac, P., \& Vlahinić Lenz, N. (2015). Uloga energije s aspekta ekonomske teorije, Ekonomski pregled, 66(6), 527-557.

Jovanović-Gavrilović, B., (2013). Privredni razvoj sa ljudskim likom. Beograd: Centar za izdavačku delatnost Ekonomskog fakulteta Univerziteta u Beogradu.

Kander, A., \& Stern, D. (2014). Economic growth and the transition from traditional to modern energy in Sweden. Energy Economics, 46, 56-65.

Mandal, Š., Mihajlović Milanović, Z., \& Nikolić, M. (2010). Ekonomika energetike: strategija, ekologija $i$ održivi razvoj. Beograd: Centar za izdavačku delatnost Ekonomskog fakulteta Univerziteta u Beogradu.

Nafziger, E. (2012). Economic development. New York: Cambridge University Press.

Ockwell, D. (2008). Energy and economic growth: Grounding our understanding in physical reality. Energy Policy, 36(12), 4600-4604.

Saks, Dž. (2014). Doba održivog razvoja, Beograd: Centar za međunarodnu saradnju i održivi razvoj i Službeni glasnik.

Sredojević, D., Cvetanović, S., \& Bošković, G. (2016). Technological Changes in Economic Growth Theory: Neoclassical, Endogenous, and Evolutionary-Institutional Approach. Economic Themes, 54(2), 177-194.

Stern, D. (2011). The role of energy in economic growth. Annals of the New York Academy of Sciences, 1219(1), 26-51.

Todaro, M., \& Smith, S. (2015). Economic development. Boston: Pearson.

Vlahinić-Dizdarević, N., Žiković, S. (2011). Ekonomija energetskog sektora izabrane teme. Rijeka: Ekonomski fakultet Sveučilišta u Rijeci. 
132 | THE QUESTION OF ENERGY AND CONSIDERATION OF ITS PLACE AND IMPORTANCE IN CLASSICAL AND NEOCLASSICAL THEORY OF GROWTH AND DEVELOPMENT

Wrigley, E. (2010). Energy and the English Industrial Revolution. Cambridge University Press, Cambridge.

Delivered: 16.12.2018. Accepted: 19.03.2019 